\title{
Seasonal variability on the structure of sublittoral macrozoobenthic association in the Patos Lagoon estuary, southern Brazil
}

\author{
Leonir A. Colling, Carlos E. Bemvenuti \& Michel S. Gandra
}

Laboratório de Ecologia de Invertebrados Bentônicos, Departamento de Oceanografia, FURG. Av. Itália Km 8, Caixa Postal 474, 96203000 Rio Grande, RS, Brasil. (andre_colling@yahoo.com.br; docbemve@furg.br)

\begin{abstract}
The aim of this study is to analyze and relate the spatial-temporal variability of macrozoobenthic assemblages to bottom characteristics and salinity fluctuations, in an estuarine shallow water region of Patos Lagoon. Monthly samples, between September 2002 and August 2003, were taken on six sampling stations (distant $90 \mathrm{~m}$ ). Three biological samples with a $10 \mathrm{~cm}$ diameter corer, one sample for sediment analysis, fortnightly bottom topography measurements, and daily data of temperature and salinity were taken from each station. Two biotic and environmental conditions were identified: the first corresponding to spring and summer months, with low macrozoobenthos densities, low values of salinity, small variations in bottom topographic level and weak hydrodynamic activity. A second situation occurred in the months of fall and winter, which showed increased salinity, hydrodynamics and macrobenthos organisms. These results which contrast with previous studies carried out in the area, were attributed to failure in macrozoobenthos recruitments during summer period, especially of the bivalve Erodona mactroides Bosc, 1802 and the tanaid Kalliapseuses schubartii Mañe-Garzón, 1949. This results showed that recruitments of dominant species were influenced by salinity and hydrodynamic conditions.
\end{abstract}

KEYWORDS. Seasonal variability, benthos, estuary, abiotic variables, sublittoral habitats.

RESUMO. Variabilidade sazonal na estrutura da associação de macroinvertebrados bentônicos em uma enseada estuarina da Lagoa dos Patos, sul do Brasil. Objetiva-se analisar e relacionar a variabilidade espaço-temporal de uma associação macrozoobentônica com as características do substrato e variações da salinidade, numa enseada da região estuarina da Lagoa dos Patos. Amostragens mensais entre setembro de 2002 e agosto de 2003 foram realizadas em seis pontos de coleta distantes $90 \mathrm{~m}$ entre si. Em cada ponto foram tomadas três amostras biológicas com tubo extrator de $10 \mathrm{~cm}$ de diâmetro, uma amostra para análise do sedimento, medidas quinzenais da topografia do fundo e dados diários de temperatura e salinidade. Foram identificadas duas situações ambientais e bióticas bem definidas: uma correspondente aos meses de primavera e verão com baixas densidades do macrozoobentos, baixos valores de salinidade e pouca variação no nível do substrato, refletindo neste caso uma menor atividade hidrodinâmica. A outra situação ocorreu nos meses de outono e inverno, que mostrou uma situação oposta em relação às variáveis bióticas e abióticas. Esses resultados, que contrariam trabalhos anteriores efetuados na região, foram atribuídos a falhas nos recrutamentos do macrozoobentos durante o período de verão, especialmente do bivalve Erodona mactroides Bosc, 1802 e do tanaidáceo Kalliapseudes schubartii Mañe-Garzón, 1949. Verificou-se que os recrutamentos das espécies dominantes foram influenciados pelas condições de salinidade e pela hidrodinâmica.

PALAVRAS-CHAVE. Variabilidade sazonal, bentos, estuário, variáveis abióticas, hábitats sublitorais.

The benthic macroinvertebrate assemblages are structured by many species of molluscs, polychaetes and crustaceans, among other organisms with more than $1 \mathrm{~mm}$ size, which show direct relation to the bottom conditions, resulting in an uniformity in lifestyle, despite their distinct philogenetic origins (DAY et al., 1989). These organisms have a key role in the estuary feeding web, acting as a link between the detritus deposited on the bottom and the higher trophic levels in the system, so contributing to an important resource for larger consumers, such as birds, decapods crustaceans and fishes (Bemvenuti, 1997c). The structure of these assemblages includes attributes as specific composition, distribution, abundance, biomass, trophic relations and diversity of the organisms (LeVInTON, 1995; Pereira \& SOAREs-Gomes, 2002).

The analysis of the structure of benthic macroinvertebrates assemblages, from their attributes, has been useful in diagnostic studies and environmental monitoring (WARWICK, 1986). However, problems may arise from the interpretation of the data acquired during these studies, concerning the distinction whether they are related to pollution or the result of natural environment variability (CLARKE \& WARWICK, 1994). In this latter case, previous studies are important in order to accomplish sufficient temporal survey of the macrofauna associations and the natural variations on the environment parameters, along the water column and substrate (WeIsBERG et al., 1997).

Spatial and temporal variability have been the object of studies in many estuaries (YSEBAERT et al., 2003; Holland, 1985; NetTo \& Lana, 1994; QuiJón \& JaRAMillo, 1993; Biles et al., 2003). In the Patos Lagoon estuarine area, different studies have been conducted about benthic communities in soft bottoms, such as the macrobenthic assemblage characterization (CAPITOLI et al., 1978), temporal variability in the infralittoral and channel area (Bemvenuti et al., 1978), biological relationships (BEMVENUTI, 1987; 1988; 1994) and comparisons to other estuarine environments of southern Brazil (Rosa-Filho \& Bemvenuti, 1998). However, there is a lack of studies on the effects of dynamic processes in the water column and substrate and the consequences on distribution and abundance of benthic macrofauna in the Patos Lagoon estuarine area. The present work aimed to analyze the spatial-temporal distribution of benthic macrofauna, in relation to the bottom characteristics and salinity variations along an annual period in that lagoon. 


\section{MATERIAL AND METHODS}

Fieldwork was performed along a transect with a length of about $450 \mathrm{~m}$ in the Saco do Arraial inlet, in a shallow plain in front of the eastern margin of Pombas Island ( $\left.32^{\circ} 01^{\prime} \mathrm{S}, 52^{\circ} 07^{\prime} \mathrm{W}\right)$ in the Patos Lagoon estuarine area (Fig. 1). Six stations $90 \mathrm{~m}$ apart from each other were sampled monthly from September 2002 to August 2003. Three biological samples were taken from each station, with a $10 \mathrm{~cm}$ diameter corer, pushed $20 \mathrm{~cm}$ into the bottom. In each station, a stratified sample $(0-5$ and $5-10 \mathrm{~cm})$ of the sediment was also collected with same corer $(10 \mathrm{~cm}$ diameter), and granulometric data were obtained through sieving and pipette analysis (Suguio, 1973). Biological samples were sieved in the field, using a $0.3 \mathrm{~mm}$ mesh size, fixed with formaldehyde $4 \%$ and stained with Bengal Rose. The macroinvertebrates were separated from the sediment matter to the lower possible taxon and preserved in ethanol $70 \%$, with the aid of a stereomicroscope in the laboratory. Daily water temperature and salinity data were obtained from PELD - Programas Ecológicos de Longa Duração, Site 8 - CNPq, FURG - databank.

Aiming to evaluate the hydrodynamic effects on substrate erosion and/or accretion, and its influences upon the benthic community, bottom topography measurements were done forthnightly. Levelled references were fixed on every station (6) along the $450 \mathrm{~m}$ profile, where four bottom level measurements were also fortnightly taken.

The dominant species collected were measured with the help of a stereomicroscope ( $0.5 \mathrm{~mm}$ precision). Erodona mactroides Bosc, 1802 specimes until $1 \mathrm{~mm}$ length and Kalliapseudes schubartii Mañe-Garzón, 1949 until $3 \mathrm{~mm}$ length were classified as recruits.

Analysis of variance (One-way ANOVA, $\alpha=0.05$ ) and Tukey's contrast test was applied to evaluate the temporal variability of fine sediments ( silt + clay).

The Shannon-Wiener diversity index (H'), which integrates the number of species and its abundance in the association, and Pielou's eveness index (CLARK, 1997), were computated and submitted to analysis of variance (Two-way ANOVA, $\alpha=0.05$ ) (local $\mathrm{x}$ time), like the statistical differences of macrofauna densities too. The biological data was transformed $(\log X+1)$ (UNDERWOOD, 1997) and tested for normality (Kolmogorov-Smirnoff test) and homogeneity of variances (Cochran test and standard-deviation mean plots) prior to their use in statistical tests (UNDERWOOD, 1997). The contrast test of Tukey was applied whenever significant results occurred (MagurRan, 1998).

A multi dimensional scaling ordination technique (MDS) was applied employing the Bray-Curtis similarity index on $\log (\mathrm{X}+1)$ transformed species data. A similarity analysis (ANOSIM; $\alpha=0.05$ ) was performed to verify possible differences between sample stations. Simper analysis was used to verify the species contribution to similarity between groups of samples (confirmed by ANOSIM) (CLARKE \& WARWICK, 1994).

\section{RESULTS}

The salinity data showed low values during the first 4 months, previous to sampling period (Fig. 2). This pattern was also observed after the beginning of macrozoobenthos sampling (September, 2002) and remained until late summer (February, 2003) (Fig. 2). In this period, the salinity data showed low values with fortnightly means not higher than 5, except in September, 2002. An increase in salinity was verified from the second fortnight of February, 2003, when it reached up to 28, as well as fortnightly means above 5 (Fig. 2). Monthly means of temperature rised gradually from the beginning of spring to the end of summer $\left(14.3\right.$ to $\left.24.8^{\circ} \mathrm{C}\right)$, and fell during the months of autumn and winter $\left(23.1\right.$ to $\left.16.6^{\circ} \mathrm{C}\right)$ (Fig. 2).

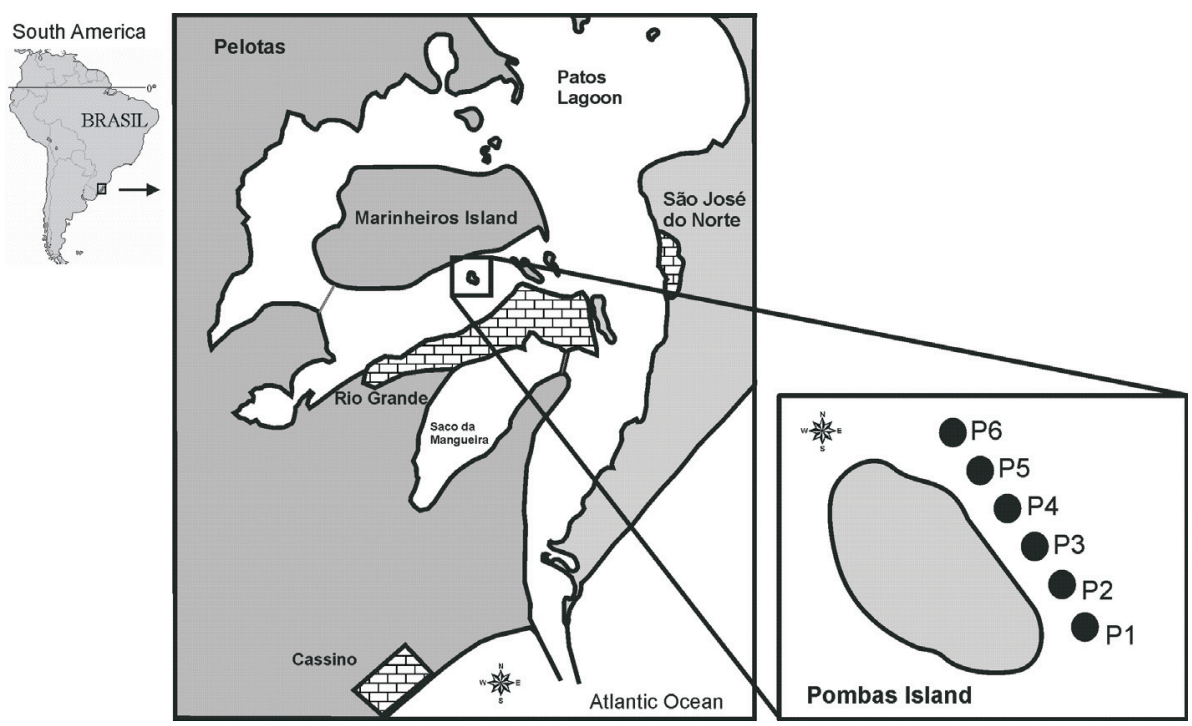

Fig. 1. Patos Lagoon estuarine region, southern Brazil, indicating the study area. P1 to P6, biological samples places. Hachured regions are inhabited zones. 
Topographical measurements showed homogeneous values between spring and winter. The higher variability was verified in the level measurements in February, 2003. This trend was marked in stations \#1, \#2 and \#3 (Figs. 3, 4) than in stations \#5 and \#6 (Fig. 5).

Grain size analysis showed that sediment of stations \#1 (4.3\%) and \#2 (5.9\%) had smaller percentages of mud (silt and clay, $<0.064 \mathrm{~mm})$, in relation to stations \#3 $(8.3 \%)$, \#4 (11.2\%), \#5 (9.6\%) and \#6 (10.5\%). Temporal variation of mud percentage showed significant differences for the winter period $(\mathrm{p}<0.05)$, when the mud content was smaller than in the other periods.

A total of 23,808 organisms were collected, corresponding to 17 species (Tab. I). The dominance was of the bivalve E. mactroides (49\%), the polychaetes Nephtys fluviatilis Monro, 1937 (12.2\%) and Heteromastus similis Southern, 1921 (12.8\%), the tanaid Kalliapseudes schubartii (15.7\%), and the isopod Munna peterseni Pires-Vanin, 1985 (3.7\%), that made-up $93 \%$ of the total macrofauna. The values of diversity $\left(\mathrm{H}^{\prime}\right)$ and eveness ( $\left.J^{\prime}\right)$ did not show significant variations $(p>0.05)$ between sampling stations, as well as between months. Benthic macrofauna showed significant differences of density ( $\mathrm{p}<0.05)$ among seasons, when it registered very low values of density in the spring $\left(2,885\right.$ ind. $\left.\mathrm{m}^{-2}\right)$ and in the summer $\left(3,782\right.$ ind. $\left.\mathrm{m}^{-2}\right)$, in contrast to higher values registered in the autumn $\left(27,028\right.$ ind. $\left.\mathrm{m}^{-2}\right)$ and in the winter $\left(22,416\right.$ ind. $\mathrm{m}^{-2}$ ) (Fig. 6).

Most of the macrobenthic species increase abundance since autumn (Fig. 6), among them arise the dominant species E. mactroides and K. schubartii (Tab. IV), that showed strong recruitments in this period.

The Ordination Analysis (MDS) (Fig. 7) showed two major groups, composed by spring and summer samples, and other group containing autumn and winter samples. This results was confirmed by ANOSIM $(\mathrm{R}=$ $0.9 ; \mathrm{p}<0.05)$.

The juveniles of E. mactroides showed significant differences of density along the six stations, in February and March ( $p<0.05)$, due to the small number of specimens found in stations \#5 and \#6. Recruitments of E. mactroides were always more intense in places with higher hydrodynamics, situated in front of the southern extremity of Pombas Island (stations \#1 and \#2), then the places with lower hydrodynamics, in an sheltered area due island protection (stations \#5 and \#6).

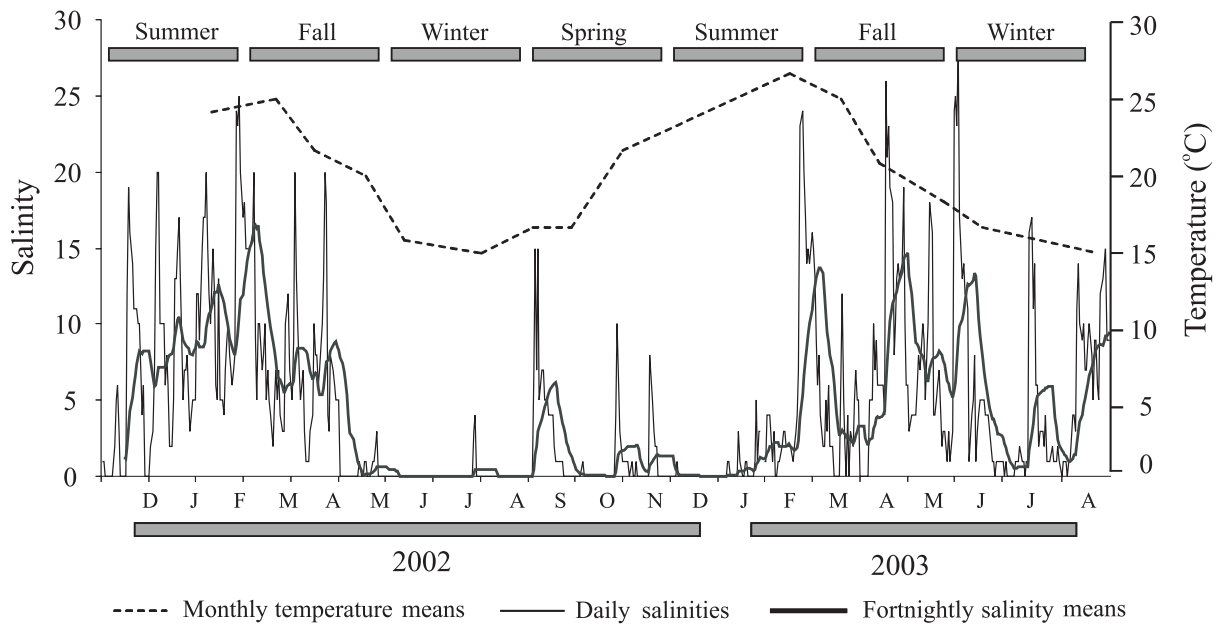

Fig. 2. Abiotic parameters (monthly temperature means, daily salinities and forthnightly salinity means) during sudy period on Patos Lagoon estuary, southern Brazil. December of 2001 to August of 2002 correspond to previous data, registerd before the sampling period.

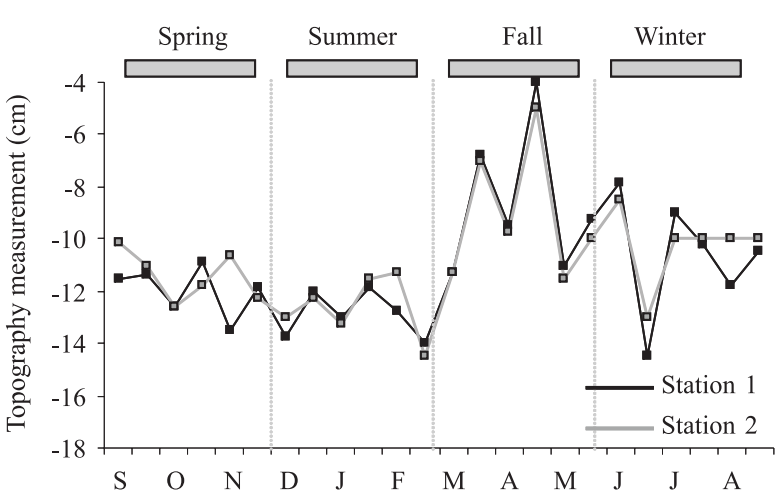

Fig. 3. Fortnightly variability $(\mathrm{cm})$ on bottom topography measurements in stations 1 and 2, Patos Lagoon estuary, southern Brazil.

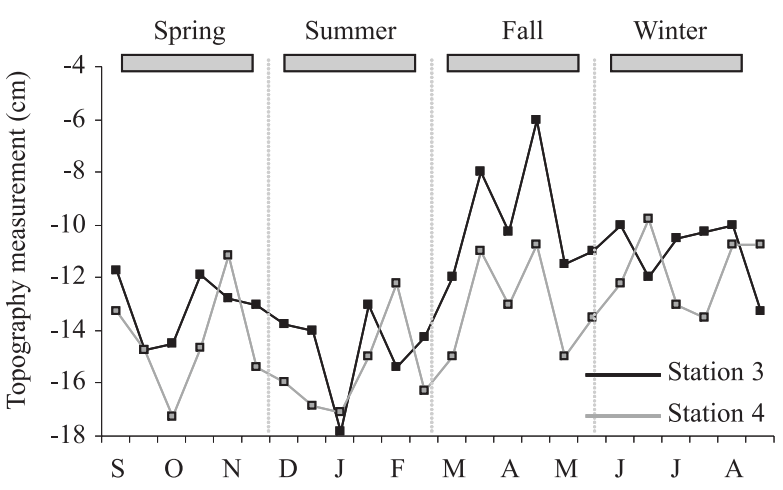

Fig. 4. Fortnightly variability $(\mathrm{cm})$ on bottom topography measurements in stations 3 and 4, Patos Lagoon estuary, southern Brazil. 
Tab. I. Values of mean density (mean) and standard deviation (Sd) (ind. $\mathrm{m}^{-2}$ ) from samples of macrofauna groups in the Patos Lagoon estuary, southern Brazil.

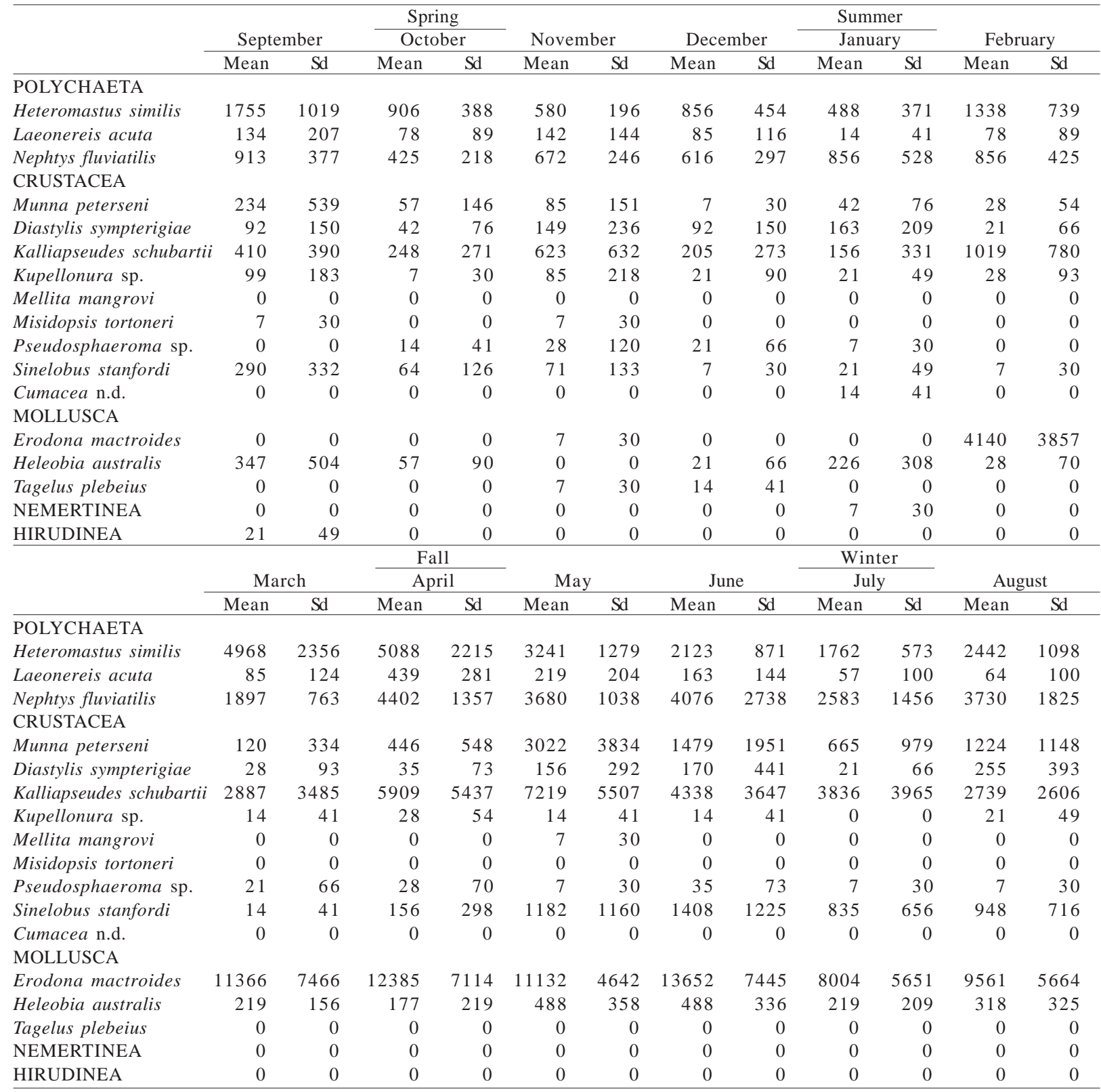

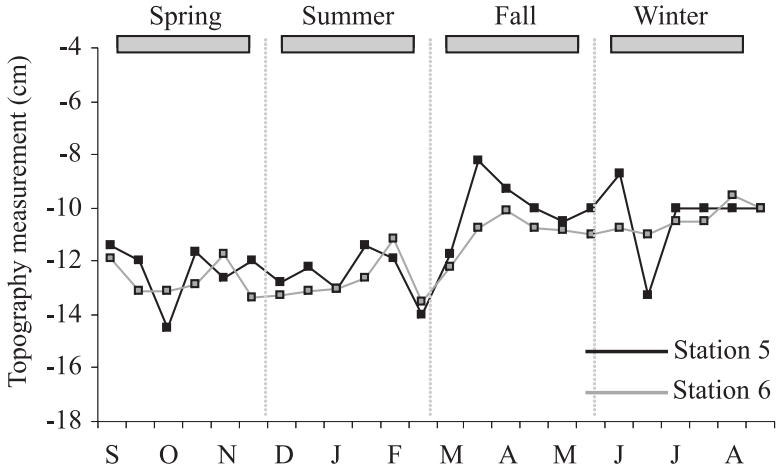

Fig. 5. Fortnightly variability $(\mathrm{cm})$ on bottom topography measurements in stations 5 and 6, Patos Lagoon estuary, southern Brazil.

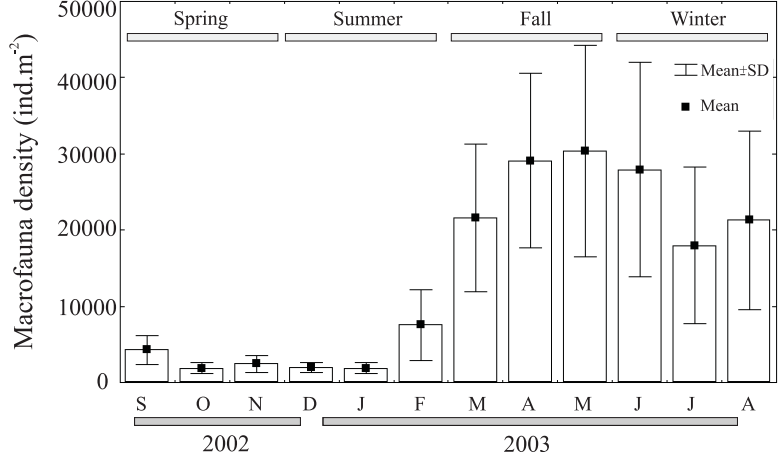

Fig. 6. Mean density (ind. $\mathrm{m}^{-2}$ ) of macrofauna for the study period in the Patos Lagoon estuary, southern Brazil. 


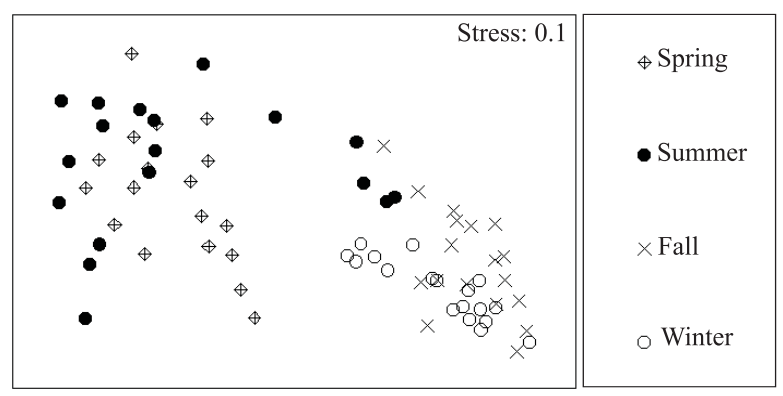

Fig. 7. Result of Multi-dimensional scaling ordination analysis (MDS) in the Patos Lagoon estuary, southern Brazil.

\section{DISCUSSION}

The results showed two well defined environmental and biotic situations: one corresponding to springsummer period, with low macrozoobenthos densities, low values of salinity and little variation in bottom level, due to low hydrodynamics, and the another corresponding to the autumn and winter period, when an opposite pattern occurred.

The low density values recorded during the summer months in the studied shallow area contrast to those obtained in previous works conducted in Patos Lagoon. BEMVENUTi (1987) found that macrozoobenthos densities recorded in summer, above 17,000 ind. $\mathrm{m}^{-2}$, were significantly higher than those found in the winter months (below 9,000 ind. $\mathrm{m}^{-2}$ ). The salinity conditions occurred in that work shows lowest salinity values in spring, with an increase in the summer - fall periods. Seasonal fluctuations in the estuarine area showed that reduction in the salinity average, during winter and spring may affect the abundance of benthic macrofauna assemblages, in contrast to summer and fall periods, with high salinity values, that increase macrozoobenthos densities, mainly due to recruitment of the dominant species (BEMVENUTI, 1987; Bemvenuti \& NetTo, 1998). Those high densities of macrozoobenthos in the summer were strongly influenced by the expressive recruitment of $K$. schubartii and coincided with the higher salinity and temperature values (BemVenuti, 1987).

It is well known that salinity influences the composition and the number of species in estuaries (LitTLE, 2000). Low salinity conditions impose severe conditions to estuarine organisms, which will therefore demand energy at high expenses, in response to osmoregulation (DAY et al., 1989). The maintance of this process could cause either mortality or inhibit their activity, limiting reproductive capacity and so its impact on future recruitment. The lower values of macrozoobenthos density coincide with low values of salinity registered between September, 2002 and February, 2003, when the estuarine area was under El-Niño influence, causing peaks of fresh water discharge, which made exceed mean values (GARCIA, 1997; GARCIA et al., 2003).

Kalliapseudes schubartii is an estuarine species which can afford high levels of investment in reproduction, so responsible for the intense recruitments in summer months in the shallow water areas of Patos
Lagoon estuarine region (BEmvenuti, 1997a, b). This species decrease its activity and seems under stress in low salinity conditions (G. Fillmann, pers. comm. Ecotoxicology Laboratory, Oceanography Department, FURG). The low salinity condition recorded during the spring-summer period, in the present study may have influenced the failures in the species recruitment.

The low E. mactroides recruitments intensity also influenced the low densities recorded in the present work, during the summer. These bivalve adult stocks are in northern portion of the estuarine area (BEMVENUTI $e t$ al., 1978) as well along the pre-limnic and limnic area at the extreme northern section of Patos Lagoon (BEMVENUTI \& NeTto, 1998). The species reproduction occurs in these areas and larvae drift along in the ebb tides colonizing the southern estuarine area, between late spring and the end of summer (BEMVENUTI et al., 1978). This reproductive pattern in which larvae arrival depends on water transportation makes the recruitment of E. mactroides to be unpredictable in time and space (BEMVENUTI, 1997b). This pattern was also observed by the authors, during long term studies beginning in 1996 (PELD - Project, Site 8 - Patos Lagoon Estuary, unpublished data).

The fact that recruitment of E. mactroides had not ocurred in the summer, only in the autumn in the present work, as shown in the works carried out by JORCIN (1996), influenced upon the macrozoobenthos densities, which recorded lower values than those registered in the study carried out by Bemvenuti (1987). The coincidence between higher levels of recruitment in time (autumn) as well in space (stations \#1 and \#2), under greater hydrodynamics, reinforce the influence of this variable upon the distribution and abundance of the species in the southern area of Patos Lagoon estuary. In subtropical and temperate zones, summer periods are characterized by the settlement of new individuals into the coastal benthic system, due to the enhancement of the reproductive process and recruitment of macrozoobenthos. Therefore, environmental patterns such as salinity changes and hydrodynamic forces, that cause recruitment variability, add a relevant aspect on the dynamics of the benthic associations in temperate estuarine regions.

Acknowledgements. To the two anonymous referees who increased the quality of the manuscript. To the financial support from FAPERGS and CNPq (PELD - Programas Ecológicos de Longa Duração). Thanks also to Nilton Abreu, for help in the Laboratório de Ecologia de Invertebrados Bentônicos Departamento de Oceanografia, FURG.

\section{REFERENCES}

Bemvenuti, C. E. 1987. Predation effects on a benthic community in estuarine soft sediments. Atlântica 1:5-32.

.1988. Impacto da predação sobre Heteromastus similis Southern, 1921 e Nephtys fluviatilis Monro, 1937 (Annelida, Polychaeta), em fundos moles estuarinos. Atlântica 10(1):8-102.

.1994. O poliqueta Nephtys fluviatilis Monro (1937) como predador da infauna na comunidade de fundos moles. Atlântica 16:87-98.

.1997a. Benthic invertebrates. In: SeEliger, U.; Odebrecht, C. \& Castello, J. eds. Subtropical convergence marine ecosystem. The coast and the sea in the warm temperate southwestern Atlantic. Heidelberg, Springer Verlag. p.43-46. 1997b. Unvegetated intertidal flats and subtidal bottoms. In: 
Seeliger, U.; Odebrecht, C. \& Castello, J. eds. Subtropical convergence marine ecosystem. The coast and the sea in the warm temperate southwestern Atlantic. Heidelberg, Springer Verlag. p.78-82.

1997c. Trophic structure. In: Seeliger, U.; Odebrecht, C. \& Castello, J. eds. Subtropical convergence marine ecosystem. The coast and the sea in the warm temperate southwestern Atlantic. Heidelberg, Springer Verlag. p.70-73.

Bemvenuti, C. E.; Capitoli, R. R. \& Gianuca, N. M. 1978. Estudos de ecologia bentônica na região estuarial da Lagoa dos Patos. II - Distribuição quantitativa do macrobentos infralitoral. Atlântica 3:23-32.

Bemvenuti, C. E. \& Netto, S. 1998. Distribution and seasonal patterns of the sublittoral benthic macrofauna of Patos Lagoon (South Brazil). Revista Brasileira de Biologia 58(2):211-221.

Biles, C. B.; Solan, M.; Isaksson, I.; Paterson, D.; Emes, E.; Raffaelli, D. G. 2003. Flow modifies the effect of biodiversity on ecosystem functioning: an in situ study of estuarine sediments. Journal of Experimental Marine Biology and Ecology 285-286:165-177.

Capitoli, R. R.; Bemvenuti, C. E. \& Gianuca, N. M. 1978. Estudos de ecologia bentônica na região estuarial da Lagoa dos Patos. I As comunidades bentônicas. Atlântica 3:5-22.

ClaRK, R. B. 1997. Marine pollution. Oxford, Claredon. 161p.

Clarke, K. R. \& Warwick, R. M. 1994. Changes in marine communities: an approach to statistical analysis and interpretation. Plymouth, Natural Environmetal Research Council. 234p.

Day, J. W.; Hall, C. A. S.; Kemp, W. M. \& Yáñez-Arancibia, A. 1989. The estuarine bottom and benthic subsystem, In: DAY, J. W. ed. Estuarine ecology. New York, John Wiley \& Sons, p. 338-376.

Garcia, C. A. E. 1997. Hydrographic characteristics. In: SEeliger, U.; Odebrecht, C. \& CAstello, J. eds. Subtropical convergence marine ecosystem: the coast and the sea in the warm temperate southwestern Atlantic, Berlin, Berlin SpringerVerlag. p.18-20.

Garcia, A. M.; Vieira, J. P. \& Winemiller, K. O. 2003. Effects of 1997-1998 El Niño on the dynamics pf the shallow-water fish assemblage of the Patos Lagoon Estuary (Brazil). Estuarine, coastal and shelf Science 57:489-500.
Holland, A. F. 1985. Long-term variation of macrobenthos in an mesohaline region of Chesapeake Bay. Estuaries 8:93-113.

JorCIN, A. 1996. Distribución, abundancia y biomassa de Erodona mactroides (Mollusca, Bivalvia, DAUDIN, 1801), em la Laguna de Rocha (Dpto. De Rocha, Uruguay). Revista Brasileira de Biologia 56(1):155-162.

LEVINTON, J. S. 1995. Marine biology: function, biodiversity, Ecology. New York, Oxford University Press. 420p.

LitTle, C. 2000. The biology of soft shores and estuaries, New York, Oxford University. 252p.

Magurran, A. E. 1998. Ecological diversity and its measurement. London, Chapman \& Hall. 242p.

Netto, S. A. \& Lana, P. C. 1994. Effects of sediment disturbance on the structure of benthic fauna in a subtropical tidal creek of southeastern Brazil. Marine Ecology Progress Series 106:239-247.

Pereira, R. C. \& Soares-Gomes, A. eds. 2002. Biologia marinha. Rio de Janeiro, Interciência. 382p.

QuiJón, P. \& JARAmillo, E. 1993. Temporal variability in the intertidal macroinfauna in the Queule River Estuary, SouthCentral Chile. Estuarine, Coastal and Shelf Science 43(5):655-667.

Rosa-Filho, J. S. \& C. E. Bemvenuti. 1998. Caracterización de las comunidades macrobentónicas de fondos blandos en regiones estuarinas de Rio Grande do Sul (Brasil). Thalassas 14:43-56.

Suguio, K. 1973. Introdução à sedimentologia. São Paulo, EDUSP. 317p.

UNDERWOOD, A J. 1997. Experiments in ecology - their logical design and interpretation using analysis of variance. Cambridge, Cambridge University. 504p.

WARWICK, R. M. 1986. A new method for detecting pollution effects on marine macrobenthic communties. Marine Biology 92:557-562

Weisberg, S. B.; Ranasingue, J. A.; Dauer, D. M.; Scaffner, L. C.; Diaz, R. J. \& Ftithsen, J. B. 1997. An estuarine benthic index of biotic integrity (B-IBI) for Chesapeake Bay. Estuaries 20(1):149-158.

Ysebaert, T.; Herman, P. M. J.; Meire, P.; Craeymeersch, J.; Veerbek, H.; Heip, C. H. R. 2003. Large-scale spatial patterns in estuaries: estuarine macrobenthic communities in the Schelde estuary, NW Europe. Estuarine, coastal and shelf Science 57:335-355. 